\title{
Dentistry Practice: Impact of Covid-19 Pandemic
}

Sanjay Prasad Gupta

Author Info:

Assistant Professor and Consultant Orthodontist, Orthodontics and Dentofacial Orthopedics unit, Department of Dentistry, Tribhuvan University Dental Teaching Hospital, MMC, Institute of Medicine, Kathmandu, Nepal

\section{Corresponding Author:}

Dr. Sanjay Prasad Gupta Email:

sanjayagupta2000@gmail.com, Contact: +977-9843585923

\section{BACKGROUND}

Our world is under siege by a viral disease, named Corona virus disease 2019 (Covid-19). Corona virus (SARS-CoV-2) is transmitted directly from person to person by respiratory droplets through coughing, droplet inhalation transmission, sneezing, and indirectly through contact transmission with nasal, oral and eye mucous membranes contact. It is also transmitted to others by fecal-oral routes and saliva. ${ }^{1}$ In addition, it was confirmed that cases without symptoms can spread the virus. ${ }^{2-3}$

\section{Why dentistry is a risk branch?}

The prime modes of containing this pandemic are enforcing effective social/physical distancing and use of masks but unfortunately it is not possible during carrying the dental procedures. Dental teams are at greater risk of infection as well as potentially transmit to others due to the nature of dentistry practice, specificity of its procedures, which involves face-to-face close contact, unable to worn masks by the patient during dental treatment, and frequent exposure to blood, saliva and other body fluids, and sharp instruments handling.

\section{Quick Response (QR) Code}

Scan Me for Full Text

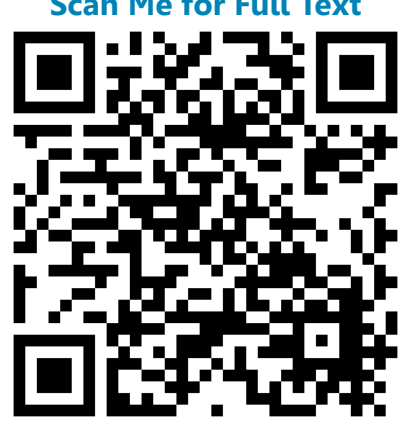

$$
\text { View PDF }
$$

\section{Article Info}

Received: 20 July 2020; Accepted: 29 July 2020; Published Online: 30 July 2020

How to cite this article in Vancouver Style?

Gupta SP. Dentistry practice: Impact of Covid-19 pandemic. Europasian J Med Sci.2020;2(2):1-3. https://doi.org/10.46405/ejms.v2i2.125

Conflict of Interest: None Declared;

\section{Disclaimer}

Source of Support: Nil

Copyright: ( $\odot 2020$ by author(s). This is an open access article distributed under the terms of the Creative Commons Attribution International License 4.0 (http://creativecommons.org/licenses/ by/4.0/) which permits unrestricted use, distribution, and reproduction in any medium, provided the original work is properly cited.

\section{Publisher's Note}

The Europasian Journal of Medical Sciences (EJMS) (www.europasianjournals.org) is an official Journal of Nirvana Psychosocial Care Center \& Ressearch Institute (www.nirvanapscc.com). The Journal as well as publisher remain neutral with regards to any jurisdictional claims in any published articles, its contents and the institutional affiliations of the authors. 
Many dental procedures produce droplets and aerosols that are contaminated with virus. ${ }^{4}$ In dentistry, devices like high-speed dental handpiece uses air in high speed to rotate at turbine and work with the running water. It is very difficult to completely stop the generation of large amounts of droplet and aerosol mixed with patient's blood and even saliva while using the dental devices. ${ }^{5}$

Transmission of pathogenic microorganisms in dentistry through the inhalation of airborne microorganisms which is suspended for long periods in the air, ${ }^{6}$ direct contact with oral fluids, blood or other materials, ${ }^{7}$ contact of nasal, oral or conjunctival mucosa. Along with this, droplets and aerosols which is generated from an infected patients and travelled a short distance by talking and coughing without a mask, ${ }^{5}$ and indirectly through contact with contaminated surfaces and/ or instruments. ${ }^{8}$

\section{INFECTION CONTROL IN DENTAL PRACTICE}

These recommendations are advised to reduce the risk of cross transmission among dental staff and patients as well as among successive patients.

1. Preparation of waiting area and receiving area with standard distancing guidelines, airflow and respiratory transmission safety protocol. Patients should wear medical masks. Provision for hand washing and hand sanitizer facility to the patient and the accompanying persons.

2. Minimization of staff and accompanying persons with strict protocol in place for patients and accompanying persons.

3. Dental professionals should recognize a suspected case of corona virus disease. For screening, the body temperature of the individuals should be taken with contact-free forehead thermometer. Patients with fever should be deferred and immediately report to the department of infection control. For screening of the potential infection, questionnaire should be used before commencement of dental examination. ${ }^{9}$

4. Oral professionals should wash their hands throughout the procedure before and after. Dental professionals should be more cautioned to avoid touching their own mouth, nose and eyes.

5. Personal protective equipment, including protective masks, eyewear, caps, gloves, protective outwear and face shields, is strongly recommended for all dental health care givers in the hospital/clinic during this pandemic as airborne droplet is the main route for transmission during dentistry practice. For routine dental practice, particulate respirators such as $\mathrm{N}-95$ masks are recommended.

6. Mouthrinse containing oxidative agents such as $0.2 \%$ povidone or $1 \%$ hydrogen peroxide is recommended before any procedure to reduce the salivary load of oral microbes as corona virus is vulnerable to oxidation.

7. Oral examination procedure which induce the coughing should be avoided. Extraoral dental radiographies, such as cone beam CT and panoramic radiography, are preferred over intraoral radiographs.

8. Rubber dam isolation reduces the airborne particles significantly in $\sim 3$-foot diameter of the operational field by $70 \%$ during aerosol generating procedures. ${ }^{10}$ When rubber dam is applied, extra high-volume suction should be used and four handed dentistry is also to be implemented.

9. Dental handpiece with anti-retraction valves or other anti-reflux designs are highly recommended to reduce backflow of microbes as an extra preventive measure for cross-infection.

10. Strict and effective disinfection measures should be done in both clinic settings and public area including door handles, chairs, and desks.

11. Daily screening logs for staff and immediate voluntary quarantine if suspected for COVID- 19 infection.

12. The medical waste should be timely transported to the temporary storage area. The reusable items should be pretreated, cleaned, sterilized and stored according to the disinfection protocol.

Being the health care professionals, it's our responsibility to mitigate the community spread of the disease through responsible and informed actions. Along with this, we need to fulfill our professional responsibility towards our patients while protecting ourselves, our staff and environment. 


\section{REFERENCES}

1. Rodriguez-Morales AJ, MacGregor K, Kanagarajah S, Patel D, Schlagenhauf P. Going global - Travel and the 2019 novel coronavirus. Travel. Med. Infect. Dis. 2020;33:1-5 https://doi.org/10.1016/j.tmaid.2020.101578 [PubMed] [Google Scholar]

2. Huang $C$, Wang $Y$, Li X, Ren L, Zhao J, Yu T et al. Clinical features of patients infected with 2019 novel coronavirus in Wuhan, China. Lancet. 2020;395:497506. https://doi.org/10.1016/S0140-6736(20)30183$\underline{5}$ [PubMed] [Google Scholar]

3. Backer JA, Klinkenberg $D$, Wallinga J. Incubation period of 2019 novel coronavirus (2019-nCoV) infections among travellers from Wuhan, China, Euro. Surveill. 2020; 20-28. https://doi.org/10.2807/15607917.ES.2020.25.5.2000062 [PubMed] [Google Scholar]

4. Wei J, Li Y. Airborne spread of infectious agents in the indoor environment. Am. J. Infect. Control. 2016;44:102-108.https://doi.org/10.1016/j. ajic.2016.06.003 [PubMed] [Google Scholar]

5. Cleveland JL, Gooch BF. Transmission of bloodborne pathogens in US dental health care settings: 2016 update. J. Am. Dent. Assoc. 2016 (147) 729738. https://doi.org/10.1016/j.adaj.2016.03.020 [PubMed] [Google Scholar]
6. Kampf G, Todt D, Pfaender S, Steinmann E. Persistence of coronaviruses on inanimate surfaces and its inactivation with biocidal agents. J. Hosp. Infect. 2020; 104: 246-251. https://doi.org/10.1016/j. jhin.2020.01.022 [PubMed] [Google Scholar]

7. Chen J. Pathogenicity and transmissibility of 2019-nCoV-a quick overview and comparison with other emerging viruses. Microb. Infect. 2020; 22(2):69-71. https://doi.org/10.1016/j. micinf.2020.01.004 [Full text] [Google Scholar]

8. Liu L, Wei Q, Alvarez X, Wang H, Du Y, Zhu H et al. Epithelial cells lining salivary gland ducts are early target cells of severe acute respiratory syndrome coronavirus infection in the upper respiratory tracts of rhesus macaques. J. Virol. 2011; 85:4025-4030. https://doi.org/10.1128/JVI.02292-10 [PubMed] [Google Scholar]

9. Peng $X, X u X, L i Y$, Cheng $L$, Zhou $X$, Ren $B$. Transmission routes of 2019-nCoV and controls in dental practice. International Journal of Oral Science. 2020;12(9):1-6.https://doi.org/10.1038/s41368-0200075-9 [Full text] [Google Scholar]

10. Samaranayake LP, Reid J, Evans D. The efficacy of rubber dam isolation in reducing atmospheric bacterial contamination. ASDC J. Dent. Child. 1989;56:442-444. [PubMed] [Google Scholar] 